\title{
NEW DATA ON FISH COREGONUS PELED (GMELIN,1788) IN SOME WATERBODIES OF MONGOLIA
}

\author{
A.Dulmaa \\ (Institute Biology, MAS)
}

\begin{abstract}
In connection with the planned establishment of a coregonid fishery and the construction of a specialized hatchery in the area of Western Mongolia was organized with the task of studying some parts of the reproduction biology of Coregonus peled population inhabiting Lake Ulaagchnii Khar Nuur (Zavhan aimag). This species was introduced into this Mongolian lake, originally lacking any fish stock, in 1980 -1982. The samples of 11230 fish examined was collected during 1993 -1999, 2005-2011 and consisted partly of the fish originating from imported and introduced larvae and partly of the individuals belonging about $25^{\text {th }}$ generating, already born in the lake studied. Most of parameters studied, such as absolute size, weight, the population dynamics, reproduction biology, of food analyses, and fatnes observed to the during vegetation period (November - December and first half of January), when the minimum daily waters temperature drops to $4^{0}$ centigrade or less. The sex ratio is fairly balanced if the total material from all fishings is considered. During this period of peak-spawning females predominate. The average individual standard length of spawners was $400 \mathrm{~mm}$ in males and $420 \mathrm{~mm}$ in females, the average weight $700 \mathrm{~g}$ in males and $900 \mathrm{~g}$ in females. Nevertheless, all parameters under study tend slightly to deteriorate in the course of time, which is obviously a result of the gradually increasing population density and of decreasing quantity of food available in the lake.

In Khuisiin Naiman Nuur (Uburchangajskij ajmag) sexually mature at the age of $2+$ , exceptionally already at the age of $1+$, at the minimum total length of $323 \mathrm{~mm}$ and minimum weight $295 \mathrm{~g}$. Gonadosomatic index of mature females ranged 9.0 to $25.0 \%$, mean absolute fecundity averaged 58.060 eggs.
\end{abstract}

\section{Introduction.}

With increasing fishing pressure has led in recent years to a decrease in density and production of valuable species, and demands for an improvement of fishery management, especially as regards the establishment of a coregonids fish culture. It was necessary to do basic ichthyological research on the population dynamics and reproduction biology of introduced Coregonus peled.

Coregonus peled is doubtless one of the most successful objects of acclimatization in fish management and at present is spread over numerous countries of Europe and Asia. In Mongolia introduction began only in 1978
(Dulmaa,1984; Anonymous, 1983) namely in the following waterbodies: lakes Shireet, Haliut and Muchar in 1978 and 1979 (the Lakesystem Khuisiin Naiman Nuur Uburchangajskij ajmag, Lake Ulaagchnii Khar in 1980, 1982, 1986 (Zavhan aimag), Lake Khongor Ulen Nuur in 1981 (Bajan-Ulgij aimag).

The acclimatization of some coregonid fishes into certain lake systems of the Mongolia, aiming to intesify the natural fish production. All this was studied in the material from the Lake Ulaagchnii Khar and from some other lakes of the Khuisiin Naiman Nuur lake system [1]. 


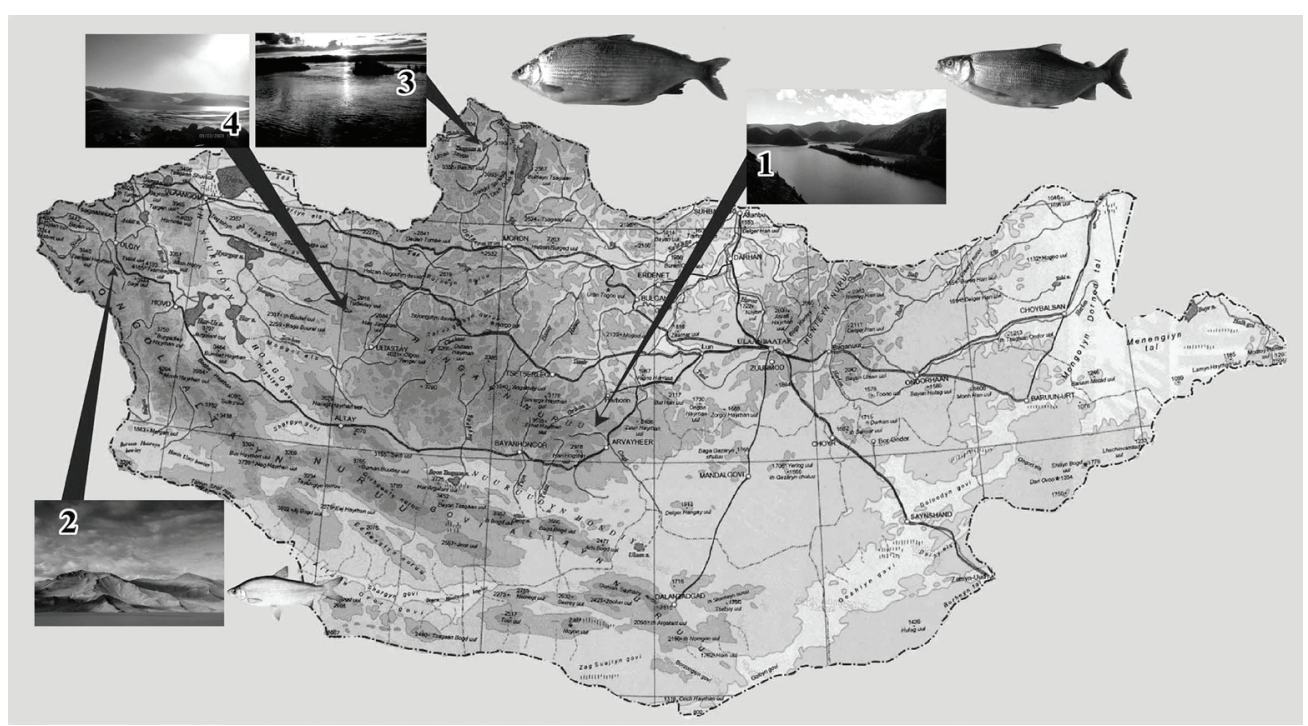

Fig.1. Distribution of Coregonus peled in Mongolia

1. Khusiin Naiman Nuur

2. Khongor-Ulen, Tolbo Nuur

\section{Material and Methods}

We examined the material of fish collected at the 12 stations in the Lake Ulaagchnii Khar $(n=11230)$ age classes $2+$ to $13+($ Tab. 1). A set of 4 gillnets with a mesh size creasing from 35 to $60 \mathrm{~mm}$ and total length of 100-300 m was used for experimental fishing. The nets were usually laid on the bottom of the lake, both in pelagial and littoral parts. All length measurements (TL, SL, FL)
3. Darhad Valey (Targan Nuur)

4. Ulaagchnii Khar Nuur

were taken from the tip of the snout. Otherwise, the standard ichthyological procedures [5] were used in studying the reproductive properties, age composition, etc. The material of Coregonus peled larvae used for introduction in Mongolian lakes was imported from the Bolshrechnsky coregonid hatchery in Buryatya, Russia, near its mouth to Lake Baikal in 1980, 1982.

Table 1

Survey of Coregonus peled analized for age and size (1996-2011)

\begin{tabular}{|c|c|c|c|c|c|c|c|c|c|c|c|c|c|}
\hline \multirow{2}{*}{ Age } & \multirow{2}{*}{$\mathrm{n}$} & \multicolumn{6}{|c|}{ Length, mm } & \multicolumn{6}{|c|}{ Weight, $\mathrm{g}$} \\
\hline & & M & $\pm \mathrm{mM}$ & SD & $\mathrm{CV}$ & $\mathrm{Pt}$ & $\pm \mathrm{t}_{\mathrm{M} M}$ & M & $\pm \mathrm{mM}$ & SD & $\mathrm{CV}$ & $\mathrm{Pt}$ & $\pm \mathrm{t} \mathrm{m}_{\mathrm{M}}$ \\
\hline $1+$ & 11 & 271 & 7,915 & 13,75 & 5,035 & 2,9 & 15,545 & 320 & 7,19 & 12,5 & 4,065 & 2,34 & 14,125 \\
\hline $2+$ & 837 & 313,3 & 17,043 & 32,252 & 19,166 & 5,3812 & 35,078 & 449,77 & 25,757 & 157,62 & 28,103 & 4,4266 & 50,98 \\
\hline $3+$ & 1023 & 347,43 & 14,711 & 24,233 & 18,706 & 4,3846 & 29,06 & 641,36 & 37,632 & 159,23 & 20,835 & 8,8313 & 69,79 \\
\hline $4+$ & 616 & 381,19 & 18,338 & 38,804 & 22,157 & 4,5987 & 36,571 & 862,09 & 67,126 & 320 & 30,319 & 23,098 & 118,51 \\
\hline $5+$ & 793 & 399,94 & 12,172 & 17,724 & 5,7747 & 3,0078 & 27,473 & 959,35 & 48,532 & 133,75 & 12,857 & 17,734 & 87,576 \\
\hline $6+$ & 304 & 435,62 & 21,127 & 61,184 & 13,507 & 4,4116 & 41,283 & 1206 & 118,87 & 580,23 & 33,677 & 31,366 & 106,4 \\
\hline $7+$ & 287 & 449,61 & 18,625 & 53,533 & 11,884 & 3,8104 & 36,586 & 1471 & 125,9 & 495,97 & 21,177 & 25,815 & 228,65 \\
\hline $8+$ & 194 & 455,54 & 30,093 & 72,235 & 15,554 & 6,2981 & 58,782 & 1472,5 & 93,767 & 283,02 & 14,254 & 61,746 & 329,06 \\
\hline $9+$ & 150 & 465,52 & 25,39 & 44,13 & 8,5438 & 4,8944 & 49,883 & 1407,3 & 94,719 & 166,14 & 10,908 & 19,97 & 177,15 \\
\hline $10+$ & 50 & 475,75 & 37,45 & 65,721 & 12,473 & 7,1356 & 74,735 & 1744,9 & 96,742 & 178,38 & 9,7417 & 20,729 & 200,56 \\
\hline $11+$ & 25 & 537 & 62,077 & 109 & 19,787 & 11,263 & 121,63 & 2057,7 & 116,73 & 227,33 & 11,093 & 57,633 & 177,21 \\
\hline $12+$ & 12 & 581,33 & 51,433 & 90,267 & 16,117 & 9,14 & 100,4 & 2455 & 101,63 & 186,67 & 7,5167 & 84,207 & 118,22 \\
\hline $13+$ & 9 & 630 & 69,2 & 120 & 19 & 10,9 & 135 & 3100 & 57,5 & 100 & 3,22 & 1,86 & 113 \\
\hline
\end{tabular}


Explanation: $\mathrm{M}$ - average, $\pm \mathrm{mM}$ - error of average, SD - standard deviation, CVcoefficient variation, $\mathrm{mCV}$-error of coefficient variation, Pt-accurary indicator, $\pm \mathrm{tm}$-confidential interval $\mathrm{P}_{005}$

\section{Study Sites}

The main objects of introduction for our country are Coregonus peled. For experimental works were selected the following reservoirs, the ecological characteristics of some of them are given below.

A droup of flowless lakes is located in the north-western part of the Hangayn Platean of the Central Asian flowless basin, at the absolute height of 1700-2150 $\mathrm{m}$ a.s.l. Among them one of the largest is the Lake Ulaagchnii Khar and it is located on the territory of Zavhan aimag, NW from the district Uliastay, Erdenehairhan somon [4]. The lake is situated among the famous Mongolian great Sand Valley "Bor-Har", which stretch for $550 \mathrm{~km}$. The lake has an ablong shape consists of several reaches with big bays and in the western part with two Islands with a height of $1980 \mathrm{~m}$ above the sea level.

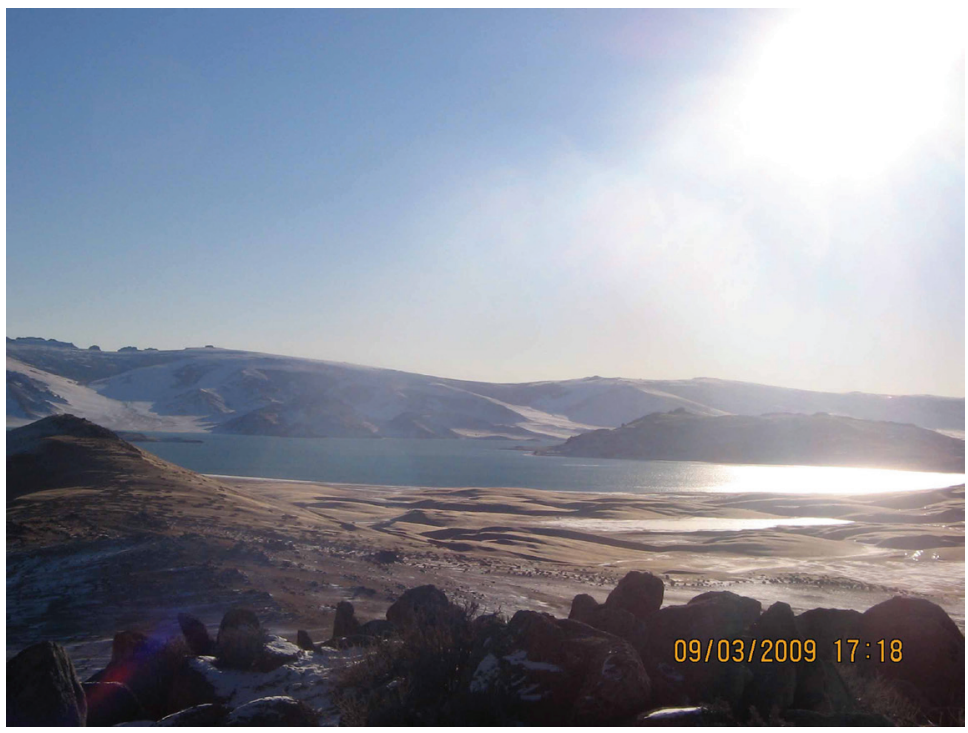

Photo 1. Lake Ulaagchnii Khar Nuur

The territory of the Lake Ulaagchnii Khar is $84.5 \mathrm{sq} . \mathrm{km}$., the lenght $36 \mathrm{~km}$, maximum width $7 \mathrm{~km}$ and maximum depth of $50 \mathrm{~m}$, average $25 \mathrm{~m}$. The litoral zone, with a depth of $5 \mathrm{~m}$, includes more than $15 \%$ of the total area. The zone limited by isobat of $10 \mathrm{~m}$ occupies $19 \%$

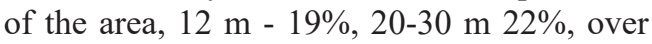
$30 \mathrm{~m}-24 \%$.

The lake"s bottom to a depth of about 5 $\mathrm{m}$ consist of gravel and sand, with clay existing exclusively at depths $>10 \mathrm{~m}$. In its deepest parts the bottom is covered with a mixture of very fine clay and a high proportion of organic matter. The lake is almost completely isolated, with only a single periodic tributary, the Ulaagchnii Gol Creek, to the north. A small stream, Telj Creek flows out from the lake"s eastern part, however it disappears into the steppe after about $50-150 \mathrm{~m}$. Spring of fresh water exist on several sites of the lake and thus create water circulation in the lake [3]. The banks of the lake are low, rocky, in some places the rocky mountains come abrupty into lake, where the substantial depth start.The W and NW banks are surrounded by sand dunes reaching sometimes a height of $200 \mathrm{~m}$ or even more.

The water in the Lake Ulaagchnii Khar is fresh, the total mineralisation is from 200 to $542.5 \mathrm{mg} / \mathrm{1}^{-1}$. It is covered by ice in the end 
of November beginning of December. The thickness of ice reaches $120-180 \mathrm{sm}$. The water temperature under ice is $1.0-2.0^{\circ} \mathrm{C}$, the transparency amounts to 7- $4 \mathrm{~m}$. The ice in the lake is broken completely at the and of June. In summertime (July-August) water is heated at the surface up to $15-25^{\circ} \mathrm{C}$, at the depth of 40-50 m $8-12^{\circ} \mathrm{C}$.

The oxygen concentration is 7.74-8.29 $\mathrm{mg} / \mathrm{l}^{-1}$ and saturation up to $85.8-97.5 \%$. Photosynthesis speed was in average $0.10 \mathrm{mgO}_{2} / 1^{-1}$ per day, with destruction $0.16 \mathrm{mgO}_{2} / \mathrm{l}^{-1}$ per day. The chlorophyll content ranged within 0.78 and $0.47 \mathrm{mg} / \mathrm{m}^{3}$. The primary production is $105 \mathrm{mgC} / \mathrm{m}^{2}$ or $115 \mathrm{kkal} /$ year [2].

In the Lake Ulaagchnii Khar is inhabited by 43 species of zooplankton including $\mathrm{Co}$ pepoda - 11, Cladocera - 10, Rotatoria -22 species. In the main forms are eurybiontic, with wide geographical spread. The prevailing complex of zooplankton during the year is Rotatoria-Copepodian with leading species of Arctodiaptomus (Rhabdodiaptomus) bacillifer, Hirudinea and Chironomidae. Their population reaches from 1.4 to 6.2 thousand/ $\mathrm{m}^{3}$ Mixodiaptomus incrassatus, Cyclops abyssorum, Daphnia (Daphnia) longispina, Keratella quadrata, which are year round. In benthos dominating are Gammarus lacustris, Mollusca with biomass from 200 to $570 \mathrm{~kg}$ / $\mathrm{ha}^{-1}$ The most richly population zone is the zone of silted sands and silts with Chara foetida and Fontinalis antipyretica, which is strongly represented by Gammarus lacustris that occupies over the half of the total biomass weight. The most poorly population is the depth zone, where test samples give 15-75 $\mathrm{kg} / \mathrm{h}^{-1}$, exclusively of Gammarus lacustris and Chironomidae, from which mainly Chironomus plumosus. The biomass of the mentioned zone is probably higher, mainly due to the fact bottom drawer does not draw completely the G. lacustris.

The Lake Ulaagchny Khar.is a highly feed reservoir. In phytoplankton dominating are diatomic and blue-green ones. The zooplankton .biomass is sufficiently high, in summer it is $6.9-10.1 \mathrm{~g} / \mathrm{m}^{3}$, in winter $1.26-3.05$ $\mathrm{g} / \mathrm{m}^{3}$. Considerable feed resources of the lake were not used because not was of fish in the lake. On the basis of theses biological data it was recommended to install into the lake larvae of Coregonus peled in 1980,1982 in total 100000 million larvae were released in to this lake [3].

Lake Khuisiin Naiman Nuur represented a system of eight consequently joined lakes (Shireet, Muchar, Halyut, Bugat, Haja, Shanaa, Doroo, Khuis) are situated in a valley of SE part of Hangai mountains, $120 \mathrm{~km}$ northerly the administrative centre Arvajheer, Uburchangajskij aimag.

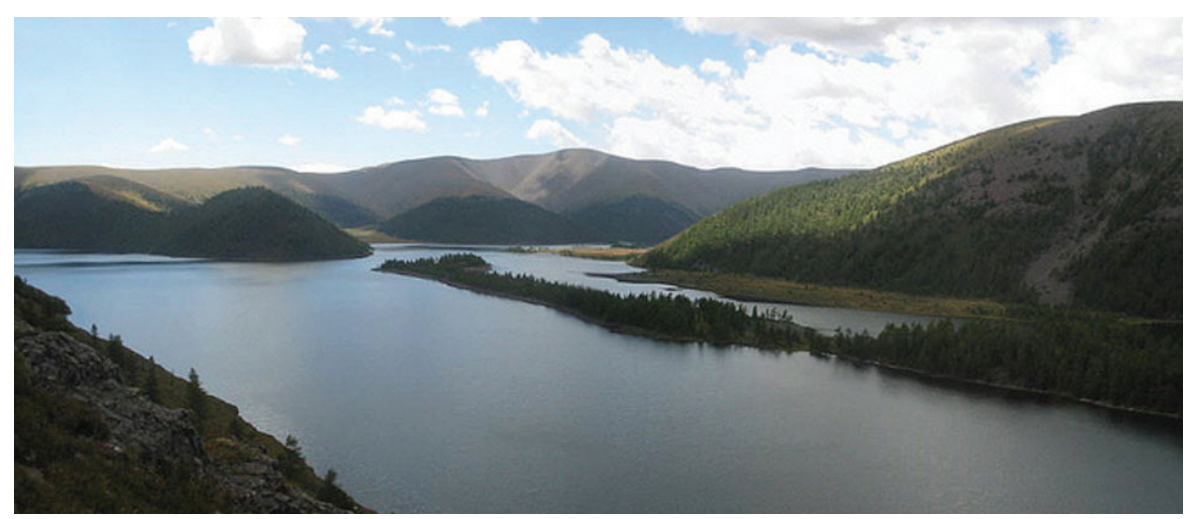

Photo 2. Lake Khuisiin Naiman Nuur 
Its elevation is 2450 m.s.l., the water area varies from 100 to 325 hectares, the maximum depth occurring in the SE part of the lake 17-25 $\mathrm{m}$, the most frequent depths are 5-10 m. The bottom relief is saucer-like. The lake is closed. No streams flow into or from it. There water collection is carried out through atmosphere precipitation, inflow of high flood waters and ground nutrition. All lakes have similar hydrobiological, hydrochimical and hydrological features. The transparency of water varies from 2.5 to $4.5 \mathrm{~m}$ the surface water temperature reaches maximally $15-18{ }^{\circ} \mathrm{C}$ during summer. As regards water chemistry, the lake is of the hydro-carbonate type and according to the degree of mineralization the "ultra-fresh" type, the total amount of salts being 58.1 to $69 \mathrm{mg} / \mathrm{l}^{-1}$. The oxygen content is very suitable reaching $7.41-8.91 \mathrm{mgO} / \mathrm{l}^{-1}$ (107.2$112.4 \%$ saturation) during May and July, $9.60 \mathrm{mgO}_{2} / \mathrm{l}^{-1}(101.5 \%$ saturation in October. Under the ice (February-March) the surface concentration of $\mathrm{O}_{2}$ changed from 7.2 to $8.0 \mathrm{mgO}_{2} / \mathrm{l}^{-1}$ (saturation $69-74.2 \%$ ). Daytime oxygen concentrations showed some oversaturation at the surface, but no other remarkable signs of eutrophication were observed. Photosynthesis speed was in average $0.63 \mathrm{mgO}_{2} / 1$ per day, with destruction $0.37 \mathrm{mgO}_{2} / 1$ per day. $\mathrm{pH}$-value range 6.97-7.20. Chlorophyll a concentration of Lake Shireet and Muhar were from 3.25 to $5.96 \mathrm{mg} / \mathrm{m}^{3}$, phytoplankton biomass $3.91-1.49 \mathrm{~g} / \mathrm{m}^{3}$ and primary production is $605 \mathrm{mgC} / \mathrm{m}^{2}$ or $730 \mathrm{kkal} / \mathrm{m}^{2}$ during the year.This lakes may be considered as mesotrophic.

Phytoplankton of the lakes presented in 33 species and ultraspecific taxon of algae belonding to 5 groups. At the head was Chlorophyta - 13 species, then following Bacillariophyta-11, Cyanopyta -7, Pyrrophyta -1, Euglenophyta - 1 species. Among the five phytoplankton taxa, dominant algae were Cyclotella comta $\left(37.3 \mathrm{mg} / \mathrm{m}^{3}\right)$, Oocystis submarina $(0.25$ $\left.\mathrm{mg} / \mathrm{m}^{3}\right)$, Synedra ulna $\left(200 \mathrm{mg} / \mathrm{m}^{3}\right)$, Melosira islandica $\left(250 \mathrm{mg} / \mathrm{m}^{3}\right)$, Scenedesmus quadricauda $-0.11 \mathrm{mg} / \mathrm{m}^{3}$.

The benthic vegetation is well developed, with up to $40 \%$ of the bottom supporting macrophytic growth. The mesotrophic lakes of Khusiin Naiman nuur shows a rich developed submerged vegetation with well developed under water meadows of varies Chara vulgaris and Fontinalis antipyretica. The following macrophytes were identified: Ceratophyllum demersum, Lemna minor, L.trisulca, Myriophyllum spicatum, Polygonium hydropiper, Phragmites australis, Spirogira sp.,Zygnema sp. In shallow of Lake Shireet the dominant species were: Myriophyllum verticillatum, Ranunculus aquaticus, Polygonium amphibium, Potamogeton pectinatus, P.praelongus, P.lucens.Helophytes were sparse but diverse, mostly Eleocharis palustris, Scirpus lacustris, Alisma lanceolata, Juncus bufonius.

Lakes Khuisiin Naiman Nuur have the highest quantity of food among the water bodies on the Hangai mountain Lake Plateau [1]. The zooplankton is composed of 20 species: Arctodiaptomus denticornis, Cyclops lacustris, Daphnia longispina, Kellicottia longispina, Conochilus unicornis are abundant of them. The biomass of zooplankton, excluding sufficiently abundant gammarids, varied $1.0-2.3(\mathrm{x}=$ 1.28) $\mathrm{g} / \mathrm{m}^{3}$ in the period prior to stocking of peled larvae into the lakes during the summer season and 0.7-1.0 ( $\mathrm{x}=0.81) \mathrm{g} /$ $\mathrm{m}^{3}$ during winter. The abundant trophical sources were not formerly utilized due to the complete absence of the fish, particularly the planktonophages. The seasonal productivity of crustaceo plankton reashed $73 \mathrm{kkal} / \mathrm{m}^{-2}$.

The benthic invertebrates include planktonic crustacean, most Gammaridae, and Ostracoda. Lake insects are also numerous. Many nektonic Heteroptera and Coleoptera feed on the bottom and 
breathe at the surface, mostly in the shallow water near shores. The planktonic larvae and nymphs of mosquitoes thrive in these lakes. In the macrophyte belts above muddy bottoms lives a rich and diverse animal benthos comprising Hydracarina, Mollusks (Lymnaea peregra, Planorbis planorbis, Gyraulus sp., Physa acuta, Radix ovata, Valvata and Pisidium casertanum. Among the insects, mostly Chironimidae with biomass $0.05-0.71 \mathrm{~g}$ dry weight per $/ \mathrm{m}^{-2}$ (Mictopsetra, Polypedilum brevianteunatum, Microtendipes, Tanytarsus, Chironomus salinaius) dragonflies and some mayflies are adapted to muddy subsrata but caddisflies are restricted to hard subsrata as are the stoneflies. Muddy bottoms are also occupied by numerous mollusks (0.12-0.48 g dry weigth per $/ \mathrm{m}^{-2}$ ) such as Lemnaea, Planorbis and Pisidium.
Benthic animal biomass in lakes Shireet 5.2, in Muchar 0.62-5.30 dry $\mathrm{g} / \mathrm{m}^{-2}$. The potential commercial productivity of fish was estimated to be $10-20 \mathrm{~kg} / \mathrm{ha}^{-1}$. There are also vast suitable spawning sites on sandy or gravel banks.

On the basis of these biological data it was recommended to stock into lakes Schireet, Muchar, Chaljut, Khuis and Bugat larvae of Coregonus peled in a quantity 1500 individuals per hectare. In May 1978 into the system of lakes Khuissin Najman Nuur were brought in 50 thousand, and in 1979, 100 thousand larvae of Coregonus peled.

Into Altaj reservoirs of the Khongor-Ulen system in Bayan-Ulgii a/mag /Har, Toson, Khongor/ and Tolbo Nuur with exclusively poor ichtyofauna the Coregonus peled was introduced in mid-May 1981. In summer of the same year the individuals reached up to $50 \mathrm{~g}$.

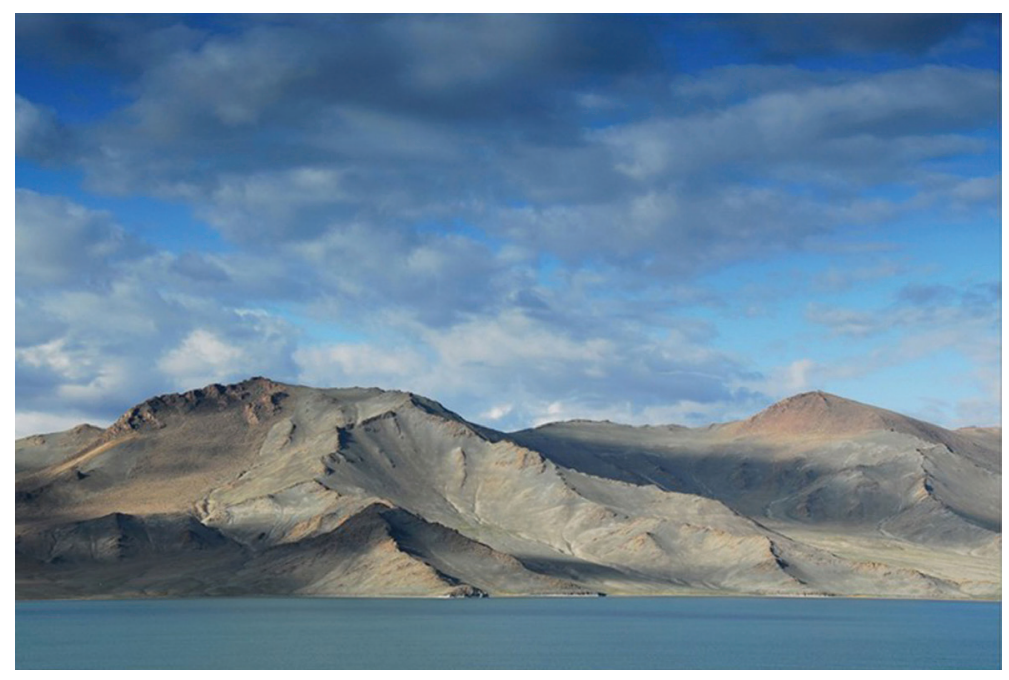

Photo 3. Lake Tolbo Nuur

Coregonus peled /Gmelin, 1778/ owing to ecological plasticity it has inhabited far beyond the limits of its areal, in reservoirs of the Central Asia. In Mongolia introduction began only in 1978 [2]. At present Coregonus peled has acclimatized well and settled all over the
Lake Ulaagchnii Khar. In the beginning of October-November starts a spawning migration toward the lake side areas of the resejrvoir. In winter the fish goes into deeper parts. $\mathrm{O}+$ yearlings weight from 75 to $120 \mathrm{~g}$. 


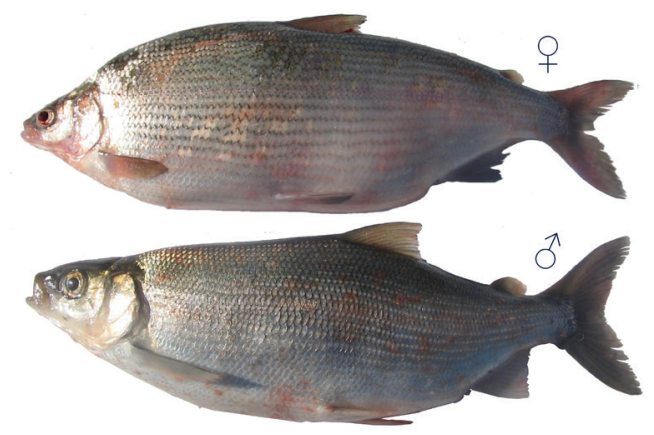

Fig.2. Coregonus peled from Lake Ulaagchnii Khar

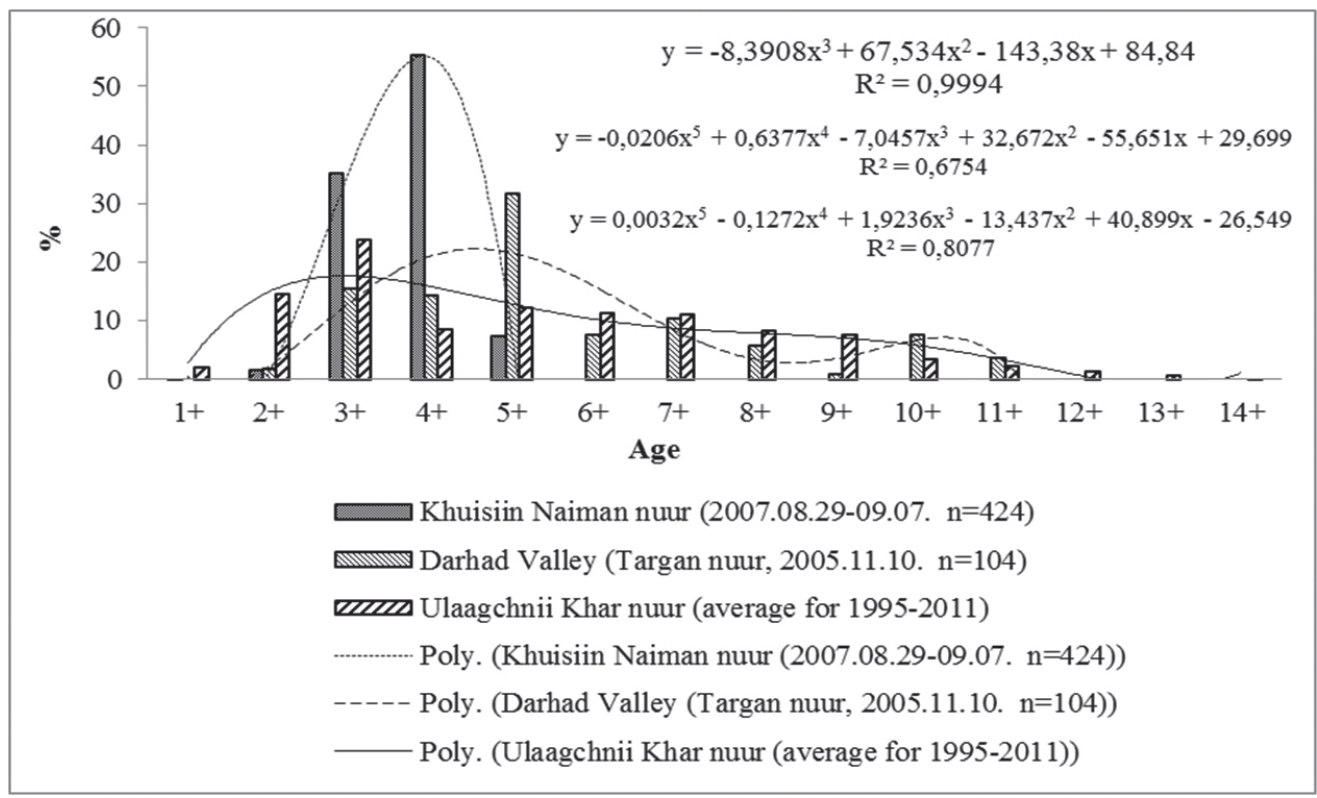

Fig. 3. Age composition of Coregonus peled

The age captured Coregonus peled was from $1+$ to $14+$ groups, the major part of the stock consisted of individuals $2+$ to $10+$ age in Lake Ulaagchnii Khar Nuur, in Khuisiin Naiman Nuur individuals of peled captured from $3+$ to $5+$ years old. In waterbodies of the Darhad valley peled have a age composition from $3+$ to $11+$ years, in the stocks dominate $5+$ year old.The grown-up fish weight varies from 350 to $3620 \mathrm{~g}$ are found at the age of $1+$ up to $14+$, but dominating are $3+-5+(87.1 \%)$ age. Coregonus peled under the conditions of sharply continental climate matures rather ear- ly on the second life year, in some cases at the age of $1+$ with achieving minimum length of $323 \mathrm{~mm}$ end minimum weight of $295 \mathrm{~g}$.

In Khuisiin Naiman Nuur yearling C.peled weight $120 \mathrm{~g}$, adult fish of $1+-5+$ ages weighted between 230 and 335 g, corresponding to a length of 214 and $341.2 \mathrm{~mm}$, respectively. In the Darhad valley for summer $3+-9+$ old individuals of C.peled had a body length of 245-450 mm, weighted 330-1200 g. In lake Ulaagchnii Khar Nuur the individuals of $3+$ to $9+$ age were in average $323-520 \mathrm{~mm}$ and $397-2560 \mathrm{~g}$. 


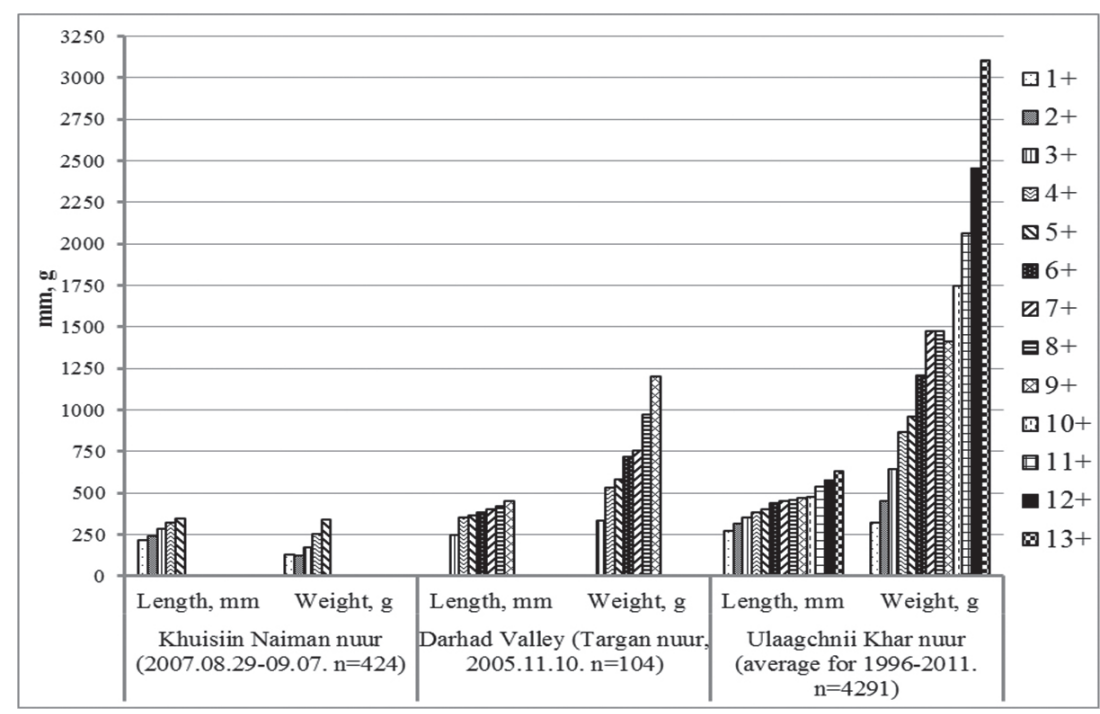

Fig.4.The size and weight of Coregonus peled in different ages

The rate of growth of peled whitefish population-acclimatizants is high and is closely related to temperature and feeding features of reservoir. According to available data, the comparatively intensive growth is noticed with peled whitefish in the system of Khuisiin Naiman Nuur, Ulaagchny Khar and Baga Nuur. When comparing the figures of growth of peled whitefish from Mongolian lakes and several reservoirs of Siberia, one can easily see that the growth rate of fishes of populationacclimatizants is rather high. The increase of the growth rate of Coregonus peled in the first years of acclimatization in reservoirs outside the natural areal, under the condition of good supply of feed, has been mentioned numerously in the literature [4].

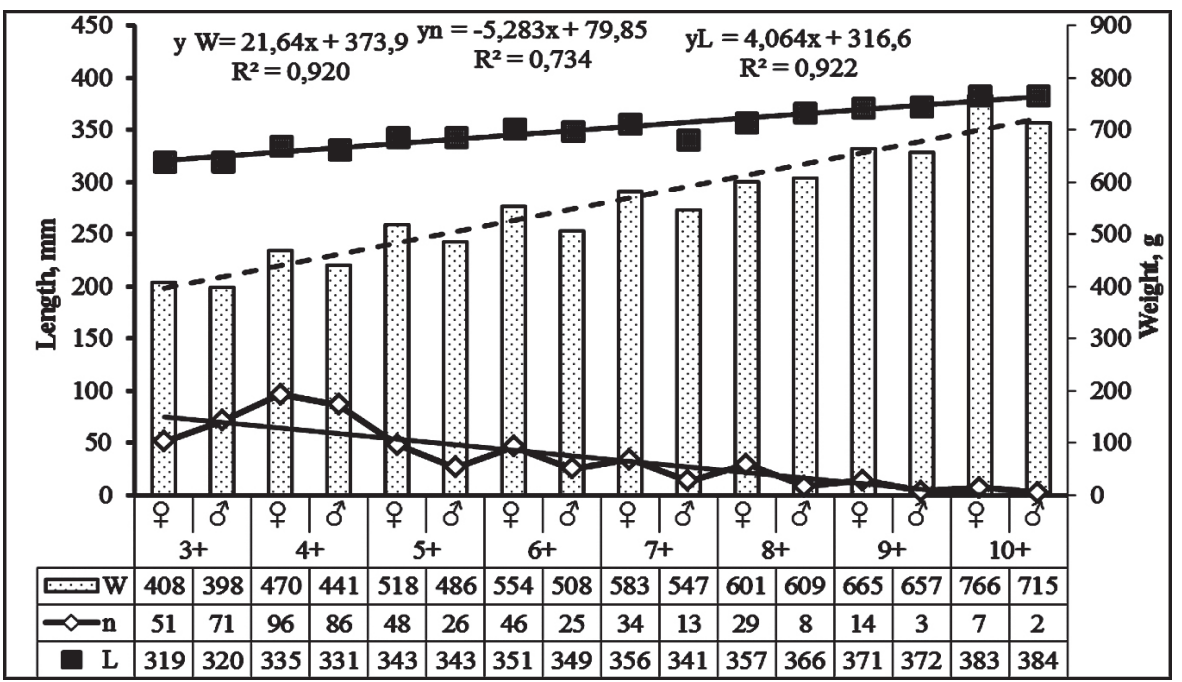

Fig.5. Growth of the female and male of C. peled in Lake Ulaagchnii Khar 
To a temporary increase in C.peled catches due the overexplotation of it. The effort resulted in extra catch about $20000-50000 \mathrm{t}$ in period 2010-2012 years. Perhaps, this may result to decrease of the size, weigh and in changing age composition Coregonus peled in the Lake Ulaagchnii Khar and Khuisiin Naiman Nuur, with comparision in 2009 year.

At the end of July sexual products of female Coregonus peled are at the II - III ${ }^{\text {rd }}$ stage of maturity, in August at the III-IY' ${ }^{\text {th }}$, in September at the IY ${ }^{\text {th }}$, in October - November at the IY-Y ${ }^{\text {th }}$, by the and of Desember and the beginning of January there are found individuals with gonads at $\mathrm{Y}-\mathrm{YI}^{\text {th }}$ stages. The gonadosomatic coefficient before spawning of female of age $2+$ varies from 9.1 to $20.0 \%$. At the end of October-mid-November some female individuals have the maximum coefficient of maturity $-25 \%$, and the minimum was in February $-0.8 \%$.

The spawning happens in November-December during the period of getting ice-bound or after it. Spawners starts at the temperature of water $2.5-1.8^{\circ} \mathrm{C}$ and the height falls on the period with water temperature of $1.5-1.0^{\circ}$ $\mathrm{C}$ under ice. Coregonus peled spawns at the depth of 1.5-4.0 m on sandy or pebbly-sandy grounds. The sex ratio of Coregonus peled among same age producers in selected waterbodies is close 1:1 (Fig.6).

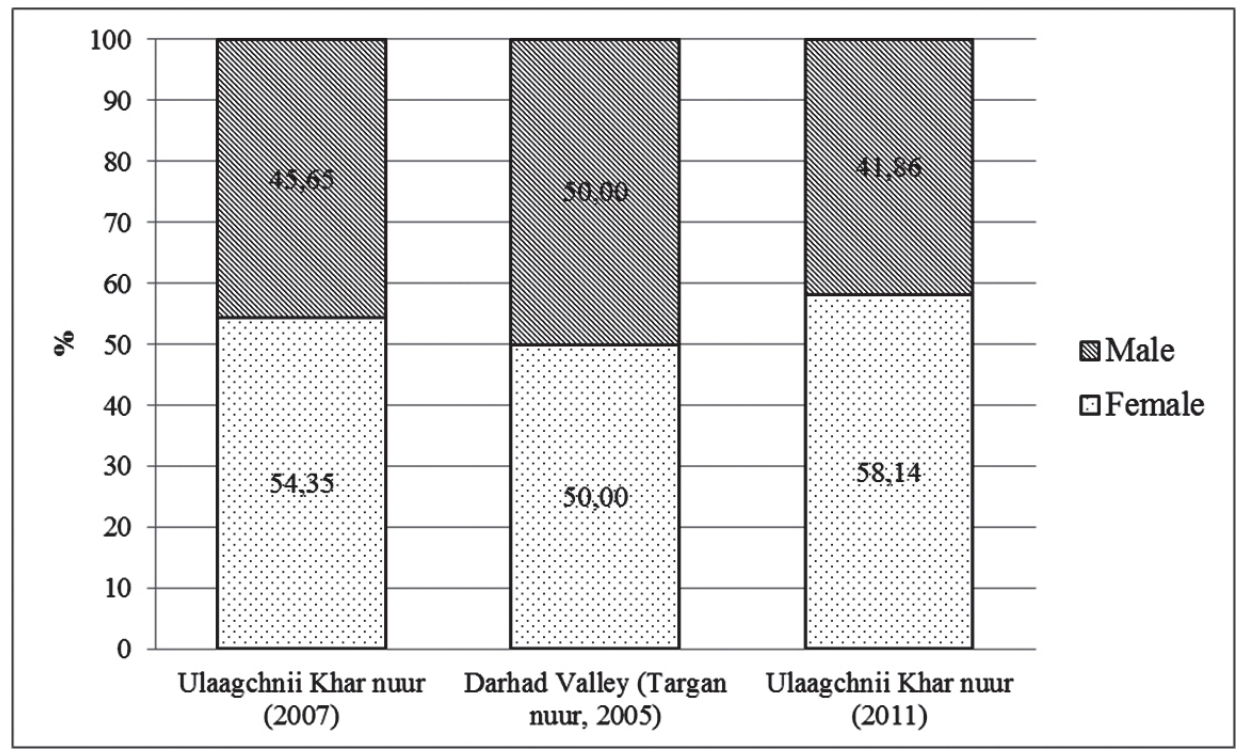

Fig. 6. Proportion of the male and female in waterbodies of Mongolia

The fluctuation level of fecundity depends rather not only the age, but the producers sizes. The growth of length and weight of fish leads to the increase of absolute fecundity (fable 2). The absolute fecundity of two yearslings fluctuates within 5.6 - 62.5 thousand eggs, of three-year-lings 7.4-77.6 thousand eggs, four-yearlings 10.8-92.2 thousand eggs, and five-yearlings $18.6-120.0$ thousand eggs. The number of eggs accounting per 1 gramm of testicle depending on the level of mature of gonads, age and mass of fishes fluctuates within 300 to 1325 eggs. The eggs is yellowish - orange, the sperm is thick consistence and of white colour. The average diameter of unswell eggs is $1.5 \mathrm{~mm}$ and of the ripened eggs reached $-2.0 \mathrm{~mm}$. The absolute fecundity of naturalized Coregonus peled varies strongly from 4.4 to 120 thousand eggs with average of 59.0 thousand. 


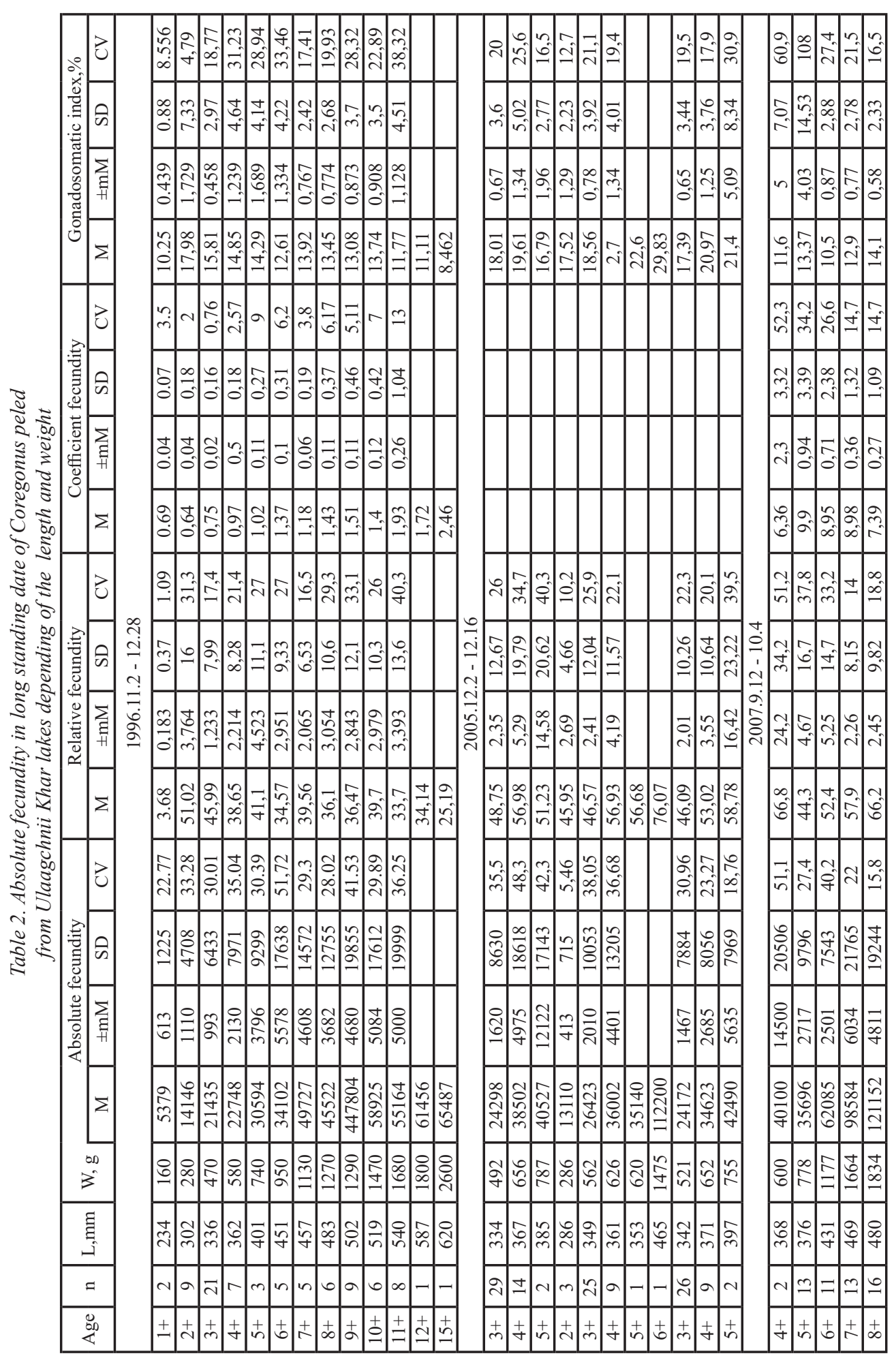




\begin{tabular}{|c|c|c|c|c|c|c|c|c|c|c|c|c|c|c|c|c|c|c|c|c|c|c|}
\hline & $\begin{array}{c}\text { a } \\
\text { a }\end{array}$ & & లై & $h$ & $\frac{0}{6}$ & & ले|ल & & $\left.\mid \begin{array}{lll}0 \\
0 \\
0\end{array}\right)$ & c) & & $\begin{array}{ll}\infty \\
a \\
m \\
m\end{array}$ & 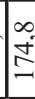 & {$\left[\begin{array}{l}n \\
3 \\
6 \\
6\end{array}\right]$} & $\stackrel{+}{\sim}+$ & & $\begin{array}{l}m \\
m \\
=\end{array}$ & & mे & 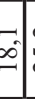 & तै & 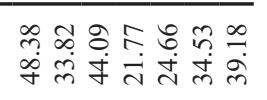 \\
\hline & : & $=$ & m & & $\hat{n}$ & ma & iौ| & & & id & & $\begin{array}{c}0 \\
0 \\
0\end{array}$ & & $\begin{array}{l}2 \\
0 \\
1 \\
-1\end{array}$ & $\dot{m}^{+}$ & & & ১ & & $\begin{array}{c}2 \\
\text { के } \\
+\end{array}$ & $\begin{array}{ll}n & ? \\
\infty & 0\end{array}$ & 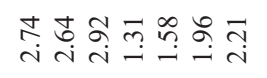 \\
\hline & 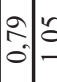 & $=0$ & I & & $\frac{\pi}{4}$ & mi: & $\pm \sqrt[7]{7}$ & & $\begin{array}{l}\nexists \\
m \\
m\end{array}$ & 8 & & 0 & in & $\mid$ & & & ñ & n. & है। & 6 & $\vec{m}=\frac{n}{-i n}$ & 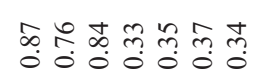 \\
\hline & $\pm \int_{2}^{2}$ & ?: & $\sigma_{0}^{\circ}$ & $\theta=$ & $\overbrace{}^{m}$ & $\left|\begin{array}{ll}\infty \\
0 \\
0\end{array}\right|$ & $4 \sqrt[4]{4}$ & & & $=$ & & : & 宓 & 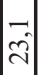 & & & iे & $m$ & $\infty$ & $\begin{array}{c}\infty \\
\cdots\end{array}$ & $\begin{array}{l}m \\
\hat{n} \\
\hat{n}\end{array}$ & 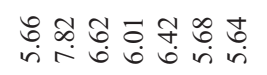 \\
\hline & 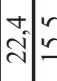 & $\hat{\imath} \mid \begin{array}{c}\infty \\
-i\end{array}$ & & 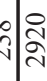 & 齐 & & ले & & $\left.\mid \begin{array}{ccc}0 & \\
i \\
m\end{array}\right]$ & 年 & & $\sqrt[7]{\frac{1}{1}}$ & - & $\begin{array}{c}2 \\
\\
2\end{array}$ & mे & & 2 & $\begin{array}{l}0 \\
\dot{f}\end{array}$ & - & की & $\begin{array}{l}0 \\
0 \\
0 \\
-0\end{array}$ & 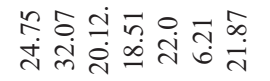 \\
\hline & 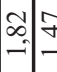 & $\rightarrow \infty$ & $\frac{\pi}{\pi}$ & & $\begin{array}{l}\stackrel{0}{n} \\
m\end{array}$ & & 辛 & & $\left(\begin{array}{c}z \\
\gamma\end{array}\right.$ & min & & -1 & $\stackrel{\infty}{\infty}$ & $\mid$ & & & $\frac{\infty}{i}$ & $\because$ & ? & $\begin{array}{c}\infty \\
\infty \\
i\end{array}$ & $\vec{\partial} \overrightarrow{\sigma_{n}}$ & 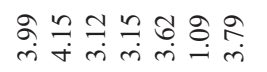 \\
\hline & 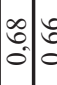 & & m & f. & הి & & $\stackrel{0}{\infty}$ & & $=$ & $=\sqrt{15}$ & & है & I & $\left(\begin{array}{c}2 \\
i \\
i\end{array}\right.$ & & & $\begin{array}{l}1 \\
0 \\
0 \\
0\end{array}$ & กิ & n. & के & $\begin{array}{ll}\overrightarrow{1} & \stackrel{2}{=} \\
0\end{array}$ & 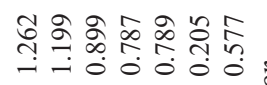 \\
\hline & $\vec{\infty} \mid \begin{array}{ll}n \\
0\end{array}$ & 2 & & $\hat{\infty}_{0}$ & {$\left[\begin{array}{l}n \\
n \\
\infty \\
\infty\end{array}\right.$} & & ?ר. & & {$\left[\begin{array}{ccc}2 \\
m\end{array}\right]$} & $=$ & & t? & $\infty$ & $\frac{7}{2}$ & & & $\mid \begin{array}{c}n \\
m \\
i\end{array}$ & 요 & $\approx$ & $\frac{2}{2}$ & 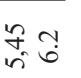 & 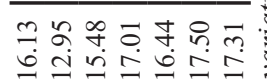 \\
\hline & $\begin{array}{l}+ \\
\dot{m} \\
\dot{m}\end{array}$ & $\underset{0}{\infty}=$ & & $\begin{array}{l}\text { ț } \\
\text { s }\end{array}$ & 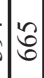 & $\frac{4}{\pi}$ & 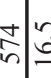 & & $\mid$ & 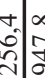 & 5 & ta & $\infty$ & $\vec{i}$ & $\left|\begin{array}{l}\infty \\
i \\
n \\
m\end{array}\right|$ & & ल. & $\begin{array}{l}n \\
i \\
n \\
m\end{array}$ & $\begin{array}{l}\infty \\
0 \\
0\end{array}$ & ले| & 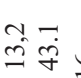 & \\
\hline & चें & $\infty$ & 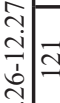 & & $=$ & $\infty$ & & is & 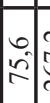 & 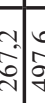 & $\frac{1}{2}$ & $=$ & $\begin{array}{l}\infty \\
0 \\
0 \\
0\end{array}$ & $\begin{array}{l}-1 \\
0 \\
0 \\
0\end{array}$ & $\stackrel{2}{3}$ & & की & $\stackrel{2}{=}$ & $\begin{array}{l}0 \\
\infty \\
\infty\end{array}$ & సी. & $\because$ & \\
\hline & 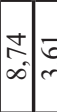 & $0=$ & & 8 in & mi & $\mid$ & & & $\begin{array}{l}\infty \\
\pm \\
\pm\end{array}$ & 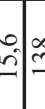 & & 0 & . & $\stackrel{+}{=}$ & 2 & & $\begin{array}{l}m \\
f\end{array}$ & $\stackrel{\infty}{\sim}$ & 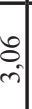 & $\hat{i}$ & & $\stackrel{N}{+}$ \\
\hline & $\overrightarrow{\mid \overrightarrow{6}}$ & & & tis. & 2 & & & & & tis & $\left\{\begin{array}{l}5 \\
i \\
i s\end{array}\right.$ & in & $a$ & $\infty$ & & & $\left(\begin{array}{c}2 \\
a \\
a\end{array}\right.$ & ते & $\begin{array}{l}0 \\
: \\
0\end{array}$ & $\begin{array}{l}+1 \\
2 \\
2\end{array}$ & $\begin{array}{l}\infty \\
\infty \\
\text { शे }\end{array}$ & \\
\hline & 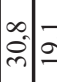 & & 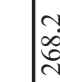 & $\begin{array}{ll}y \\
0 \\
0\end{array}$ & 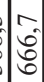 & in & & & 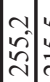 & רิ & 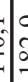 & 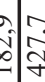 & $\stackrel{m}{m}$ & fे & & & $\begin{array}{l}0 \\
\infty \\
n \\
\cdots\end{array}$ & 0 & 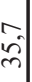 & के & $\begin{array}{l}=\infty \\
= \\
= \\
\dot{f}\end{array}$ & 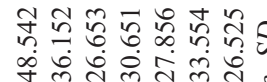 \\
\hline & & $\infty$ & & ○ & & & & & $m$ & n & S & \pm & & $\wedge$ & $-{ }_{-}$ & & -1 & ४ & $a$ & in & & \\
\hline & 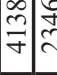 & & & & & के & & & & & & ปู & mi & 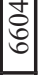 & $\left|\begin{array}{l}0 \\
0 \\
1\end{array}\right|$ & & 임 & al & 范 & $\begin{array}{l}0 \\
6 \\
6\end{array}$ & $\begin{array}{ll}\tilde{n} \\
\tilde{n}\end{array}$ & 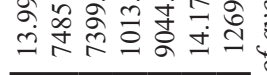 \\
\hline & \begin{tabular}{l|l}
0 \\
0
\end{tabular} & & 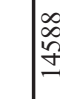 & 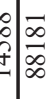 & 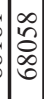 & : & & & 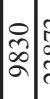 & 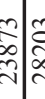 & 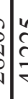 & \begin{tabular}{l|l} 
a \\
ve \\
$y$
\end{tabular} & 它 & 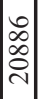 & & & 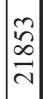 & & $c^{0}$ & $\begin{array}{l}\text { ले } \\
\frac{m}{n}\end{array}$ & 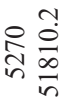 & 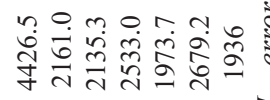 \\
\hline & 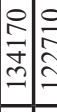 & $\begin{array}{c}0 \\
0 \\
0\end{array}$ & $\begin{array}{l}\infty \\
\infty \\
\infty \\
m\end{array}$ & 2 & 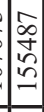 & 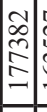 & 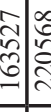 & & 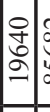 & 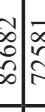 & 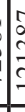 & 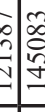 & 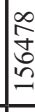 & 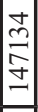 & 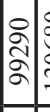 & & 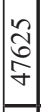 & $?$ & fo & $\begin{array}{l}\infty \\
\infty \\
\infty \\
\infty \\
- \\
\end{array}$ & 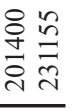 & 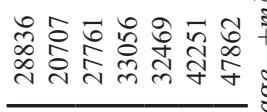 \\
\hline & 辛於 & 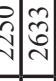 & & $\hat{\infty}$ & î & ְे & & & $\stackrel{2}{n}$ & c) & & in & & ڤે & & & 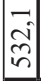 & & $\infty$ & के & શิ & 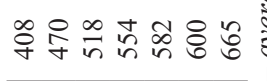 \\
\hline & in & हैं & & 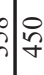 & $\stackrel{?}{+}$ & 冬 & & & $\stackrel{m}{m}$ & $\stackrel{8}{\forall}$ & & 8 & & 它 & $m$ & & $\left|\begin{array}{c}+ \\
\vdots \\
0 \\
m \\
m\end{array}\right|$ & & & - & $\begin{array}{l}\vec{n} \\
\hat{i} \\
\text { in }\end{array}$ & 욤요 \\
\hline & & & ले & 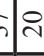 & $\bar{\imath}$ & $\%$ & & & 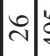 & gै & & 7 & & 요 & $\mathrm{N}$ & & $\simeq$ & & m & $r$ & बे + & 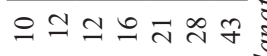 \\
\hline & 喜 & \pm & in & $\mathrm{N}^{+} \mathrm{T}$ & + & 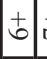 & $+\stackrel{t}{ \pm}$ & & \pm & $m$ & & & & & & & & & & t & & \\
\hline
\end{tabular}


The relative fecundity of peled whitefish ranges from 25.2 to 95.0 eggs per 1 gramm of body weight without viscera (sculled weight). The minimum indicator was observed in July 10.6 and the maximum in October-November up to 95 eggs. With the increasing sizes and mass there is observed its natural decrease. Therefore, the absolute fecundity of the peled whitefish under conditions of the lake system of Mongolia has a comparatively high figure.

In the Khuissin Naiman Nuur C.peled spawns in November-December. Fecundity is from 8795 to 24781 eggs. In the Darhad valley females produce between 23999 and 75113 eggs. The spawning season C.peled in Lake Ulaagchnii Khar Nuur takes place in December January, under water temperature descends to $1.8-2.1^{0} \mathrm{C}$, spawn peaks in $1.5-1.0^{\circ} \mathrm{C}$. Female produce 28836 to 58453 eggs. Fecundity increases with the length, weight and age ( Fig.7.)

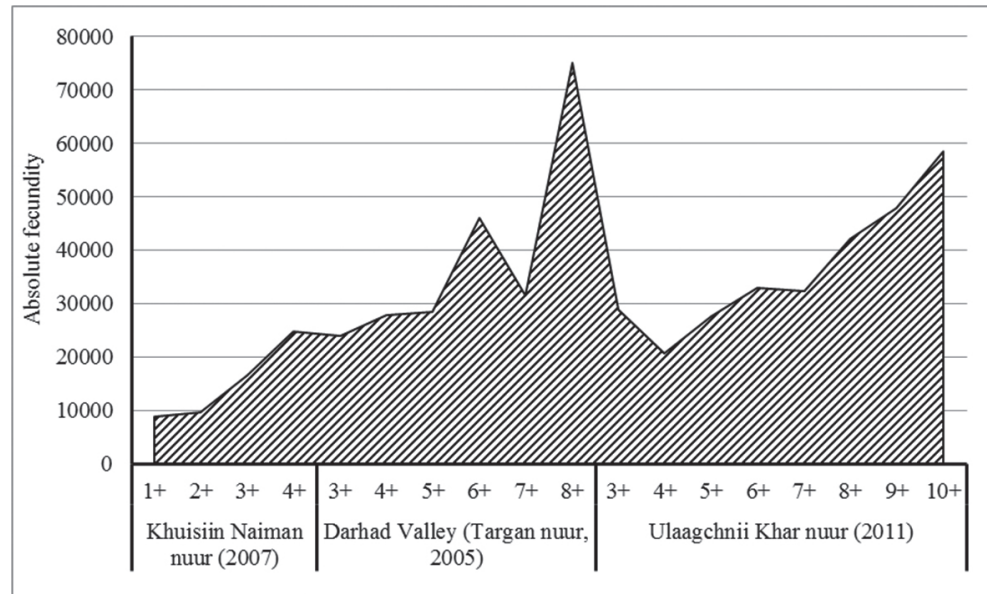

Fig. 7. Fecundity of C. peled in waterbodies of Mongolia

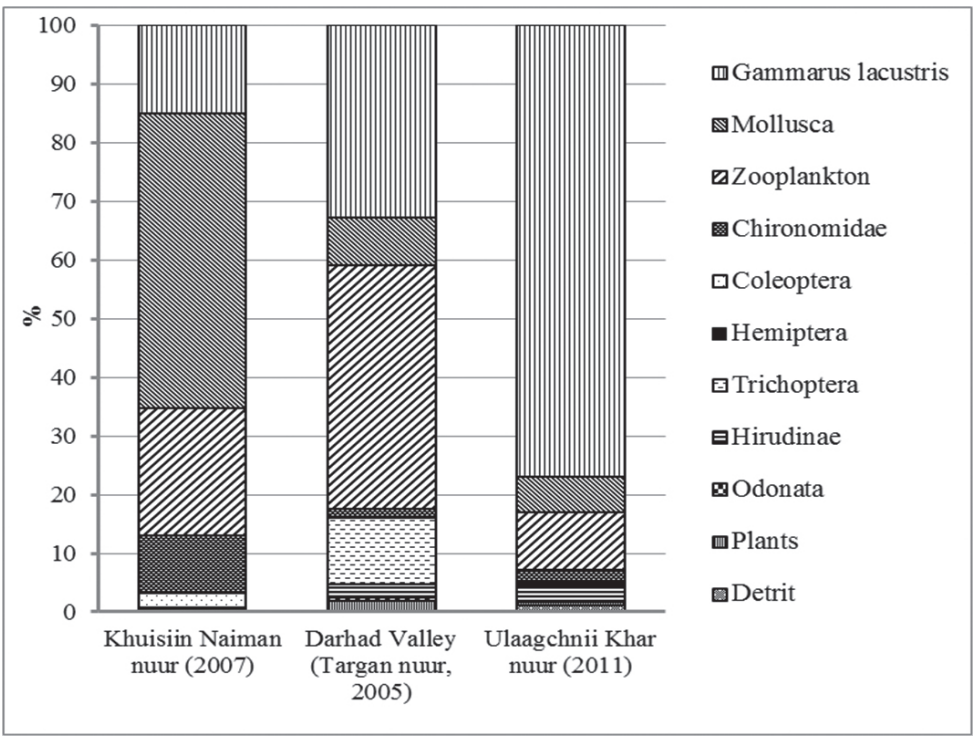

Fig. 8. Food components of Coregonus peled 
In Mongolian lakes Coregonus peled feeds year-round. The main food is planktonic crustaceans, planktonic gammarids, chironomidae and molluscs. The oldest C.peled of rivers and lakes in selected reservoirs feed mostly on benthic organisms. Plankton is the major source of food for young fish up to years old. Some of 20 species of food organisms have been identified as food items of C.peled from the Khuisiin Naiman Nuur, Darhad valley and basin of Lake Ulaagchnii Khar Nuur. The index of stomach fulness ranges from 10 to 75 o/ooo.

The fatnes coefficient by Clark is rather high and ranges within 1.4-2.67. The fatnes coefficient of mature peled whitefish in places of its natural areal varies within 1.1-1.8.

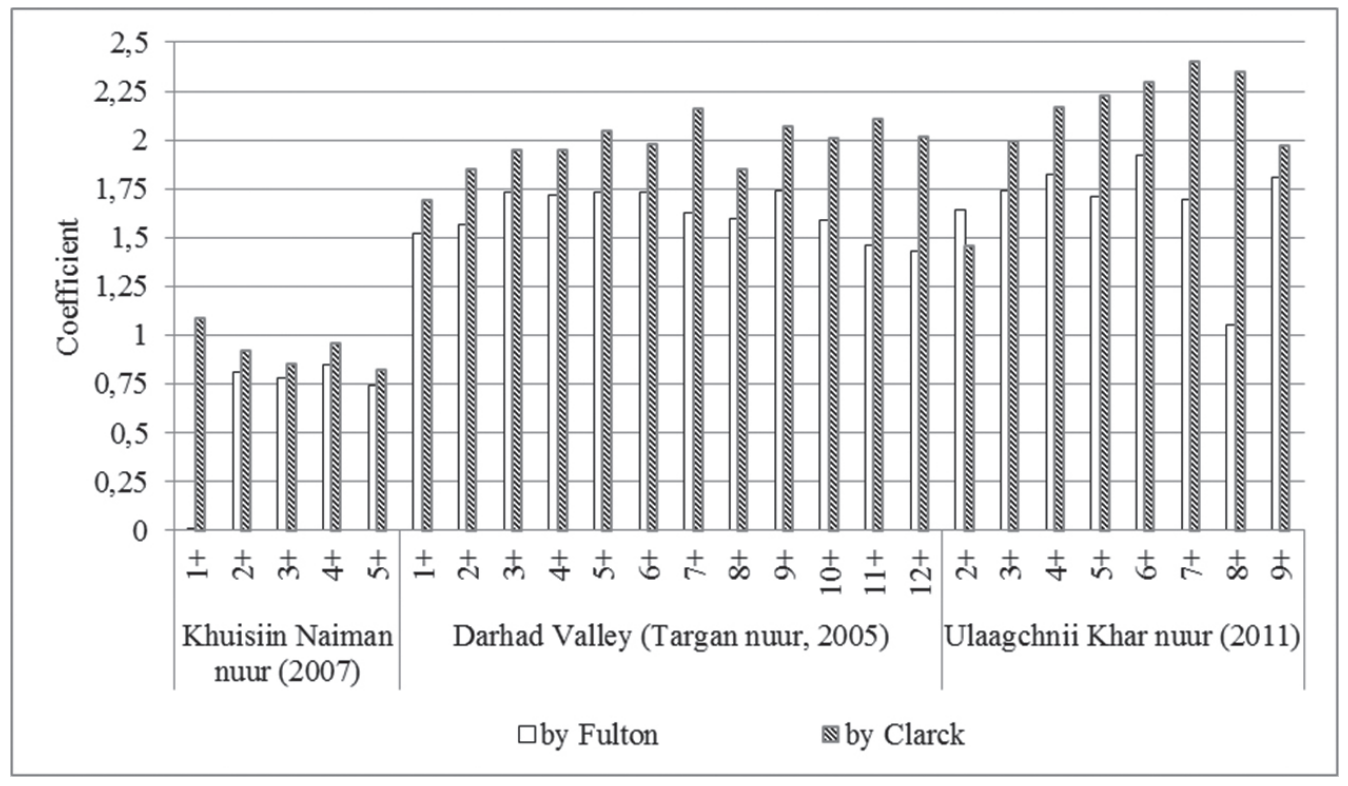

Fig.9. Coefficient fatnes of Coregonus peled

The coefficient fatnes of Coregonus peled in selected lakes very different. Lower coefficient fatnes of C.peled observed in lakes Khuissin Naiman Nuur (0.85 - 1.15), in Darhad valley $1.40-2.25$ by Fulton. The highest coefficient fatnes are found in C.peled from waterbodies Ulaagchnii Khar Nuur (1.65-2.4 by Fulton). Fig.9.

\section{Conclusion.}

At present Coregonus peled has naturalized in Mongolia. Thus, in the reservoirs in fact has appeared an additional trophic chain - consuments of first and second sequence. Based on the experience of acclimatization works, an outlook of changes in the population of Coregonus peled can be made. Its number is substantially increasing on the account of natural reproduction and fishes are growing well. In all lakes there has been formed with concentration sufficient for fishery the parent herd and introduction material for installing fish into other reservoirs of Mongolia. In the future the population is likely to grow steadity and after achieving the certain level, will stabilise. It is more likely, with growing population the Coregonus peled growth rate will slow down due to the competition of food, but no seems it for the present time in Mongolia. 


\begin{tabular}{|c|c|c|c|c|c|c|c|c|c|c|c|c|c|c|c|}
\hline \multirow{7}{*}{ 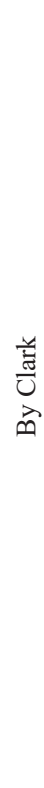 } & $\underset{H}{\sum_{H}}$ & $\mathbb{O}_{0}$ & $\stackrel{1}{0}$ & $\begin{array}{l} \pm \\
0 \\
0\end{array}$ & $\stackrel{2}{0}$ & $\hat{0}$ & $\stackrel{1}{\circ}$ & $\begin{array}{l}\text { İ } \\
\text { ô }\end{array}$ & $\stackrel{\simeq}{\stackrel{0}{0}}$ & $\frac{\partial}{0}$ & $\stackrel{m}{0}$ & $\stackrel{\infty}{0}$ & $\stackrel{\infty}{\circ}$ & तิ & $\frac{m}{0}$ \\
\hline & $\vec{a}$ & $\stackrel{\sim}{\stackrel{\sim}{-}}$ & $\hat{n}$ & 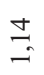 & $\stackrel{m}{\sim}$ & $\vec{\sigma}$ & $\stackrel{-}{-}$ & $\stackrel{\infty}{\infty}$ & 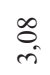 & $\begin{array}{l} \pm \\
\dot{f}\end{array}$ & $\hat{\hat{a}}$ & $\stackrel{2}{\approx}$ & $\tilde{\sigma}$ & $\stackrel{m}{*}$ & $\frac{\infty}{m}$ \\
\hline & $\begin{array}{l}\text { 己 } \\
\text { }\end{array}$ & $\begin{array}{l}\vec{\infty} \\
0 \\
0\end{array}$ & $\stackrel{\infty}{\circ}$ & $\stackrel{\infty}{\infty}$ & $\tilde{\sigma}_{-}$ & $\stackrel{ \pm}{=}$ & $\Rightarrow$ & $\begin{array}{l}\hat{0} \\
i\end{array}$ & $\stackrel{\infty}{\stackrel{\infty}{c}}$ & ते & $\vec{a}$ & $\stackrel{\mathbb{J}}{=}$ & $\stackrel{0}{\sim}$ & $\underset{\infty}{\mathbb{D}}$ & 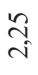 \\
\hline & 己े & बे & $\hat{m}$ & $\hat{i}$ & $\begin{array}{l}0 \\
\pm \\
\pm\end{array}$ & $\begin{array}{l}n \\
\cong\end{array}$ & $\stackrel{\infty}{\subseteq}$ & 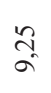 & $\frac{2}{a}$ & $\hat{m}$ & $\cong$ & $\begin{array}{l}\stackrel{0}{\circ} \\
\infty\end{array}$ & $\stackrel{ }{i}$ & $\overrightarrow{0}$ & ळे \\
\hline & के & $\tilde{3}$ & $\begin{array}{l}\text { İ } \\
\text { o }\end{array}$ & $\begin{array}{l}\text { î } \\
\text { ô }\end{array}$ & $\hat{\widehat{o}}$ & 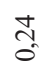 & $\begin{array}{l}\bar{\pi} \\
\text { o }\end{array}$ & $\begin{array}{l}\text { הิ } \\
\text { on }\end{array}$ & ָֻ & तु & $\begin{array}{l}\text { थे } \\
\tilde{o}\end{array}$ & $\underset{\tilde{\sigma}}{\tilde{0}}$ & $\frac{1}{0}$ & $\stackrel{\text { İ }}{0}$ & $\frac{\partial}{0}$ \\
\hline & $\sum_{\text {弄 }}$ & $\tilde{O}_{0}^{\circ}$ & ô. & ठ̃. & Oे & $\tilde{o}_{0}^{0}$ & $\tilde{O}_{0}$ & $\stackrel{0}{0}$ & $\stackrel{0}{\circ}$ & oे & $\stackrel{0}{0}$ & $\begin{array}{l}\text { I } \\
0\end{array}$ & $\begin{array}{l}\text { to } \\
0\end{array}$ & $\overrightarrow{0}$ & $\begin{array}{l}8 \\
0\end{array}$ \\
\hline & $\Sigma$ & $\stackrel{\vartheta}{\Rightarrow}$ & $\stackrel{\mathbb{I}}{\mathrm{I}}$ & $\frac{n}{i}$ & $\underset{-\infty}{+}$ & 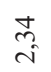 & $\stackrel{\partial}{\Rightarrow}$ & $\underset{i}{\stackrel{J}{*}}$ & ô. & 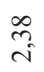 & $\begin{array}{l}\vec{i} \\
\text { in }\end{array}$ & $\begin{array}{l}\infty \\
n \\
i\end{array}$ & $\begin{array}{l}\tilde{N} \\
\tilde{d}\end{array}$ & $\begin{array}{l}\overrightarrow{6} \\
i\end{array}$ & ò \\
\hline \multirow{7}{*}{$\begin{array}{l}\text { 总 } \\
\text { 童 } \\
\text { 命 }\end{array}$} & $\underset{\Xi}{\sum_{H}}$ & $\stackrel{0}{0}$ & $\begin{array}{l}\text { to } \\
\text { O. }\end{array}$ & $\underset{0}{0}$ & $\mathbb{0}_{0}^{ \pm}$ & $\stackrel{n}{0}$ & $\stackrel{n}{0}$ & $\begin{array}{l}\text { â } \\
\text { ô }\end{array}$ & $\stackrel{m}{0}$ & $\begin{array}{l}0 \\
0 \\
0\end{array}$ & $\stackrel{\infty}{0}$ & $\hat{0}$ & \begin{tabular}{l}
$\infty$ \\
\multirow{2}{*}{}
\end{tabular} & $\vec{m}$ & $\stackrel{2}{0}$ \\
\hline & \pm & \begin{tabular}{l}
$\stackrel{+}{\sigma}$ \\
\multirow{f}{*}{}
\end{tabular} & $\stackrel{q}{\rightarrow}$ & \pm & $\stackrel{n}{\sim}$ & 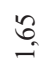 & $i$ & $\begin{array}{l}n \\
\tilde{\sigma}\end{array}$ & $\hat{i}$ & $\begin{array}{l}\vec{b} \\
\dot{*}\end{array}$ & $\frac{\infty}{a}$ & 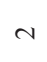 & aे & $\vec{\Xi}$ & $\begin{array}{l}\infty \\
n^{n}\end{array}$ \\
\hline & 己 & $\underset{r}{\stackrel{g}{r}}$ & $\vec{\sigma}$ & $\stackrel{\infty}{0}$ & $\stackrel{n}{\circ}$ & $\stackrel{0}{=}$ & $\exists$ & $\stackrel{\sim}{m}$ & $\stackrel{\overbrace{}}{m}$ & $\begin{array}{l}\stackrel{2}{2} \\
\stackrel{2}{m}\end{array}$ & $\stackrel{\sim}{\sim}$ & $\underset{G}{\exists}$ & $\stackrel{5}{\circ}$ & $\overrightarrow{\mathrm{I}}$ & $\begin{array}{l}\text { है } \\
+\end{array}$ \\
\hline & 己 & $\frac{3}{\delta}$ & $\begin{array}{l}\infty \\
\stackrel{\jmath}{f}\end{array}$ & 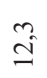 & $\stackrel{\infty}{\stackrel{n}{2}}$ & $\begin{array}{l}0 \\
\stackrel{0}{0}\end{array}$ & $\stackrel{n}{0}$ & $=$ & $\hat{\sigma}$ & $\stackrel{m}{n}$ & $\underset{+}{\text { fo }}$ & $\stackrel{\text { ڤn }}{0}$ & $\hat{\vec{m}}$ & $\begin{array}{l}\text { I } \\
\text { f }\end{array}$ & $\begin{array}{l}0 \\
\infty^{\circ}\end{array}$ \\
\hline & 命 & $\stackrel{0}{=}$ & ช̂ & $\begin{array}{l}\text { त̃ } \\
\text { o }\end{array}$ & $\begin{array}{l}\tilde{n} \\
\tilde{0}\end{array}$ & $\frac{a}{0}$ & $\frac{\partial}{0}$ & $\begin{array}{l}\tilde{n} \\
\tilde{0}\end{array}$ & $\begin{array}{l}\vec{n} \\
0\end{array}$ & 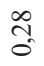 & $\frac{1}{0}$ & $\frac{a}{0}$ & $\begin{array}{l}\infty \\
n \\
0\end{array}$ & $\begin{array}{l}0 \\
0\end{array}$ & त̂ \\
\hline & $\sum_{\text {茾 }}$ & $\begin{array}{l}\infty \\
0 \\
0\end{array}$ & है & ठै. & Oे & $\stackrel{8}{0}$ & $\overbrace{0}^{0}$ & oे & \&. & $\stackrel{\infty}{\circ}$ & $\stackrel{J}{0}$ & $\tilde{O}_{0}^{0}$ & $\stackrel{ \pm}{0}$ & $\begin{array}{l}0 \\
0\end{array}$ & o. \\
\hline & $\Sigma$ & $\stackrel{\mathbb{A}}{\cong}$ & in & $\stackrel{\infty}{\rightarrow}$ & $\stackrel{\infty}{0}$ & $\underset{\infty}{\mathscr{O}}$ & $\hat{\infty}$ & $\frac{n}{i}$ & $\hat{\overbrace{}}$ & $\stackrel{\infty}{\infty}$ & $\stackrel{\infty}{\sim}$ & $\stackrel{\Omega}{g}$ & $\stackrel{\circ}{\stackrel{+}{\sim}}$ & $\hat{\sigma}$ & $\stackrel{\infty}{=}$ \\
\hline z & & Ot & ro & Ot & ro & Ot & $\kappa_{0}$ & Ot & ro & Ot & ro & Ot & ro & O+ & ro \\
\hline & $\Rightarrow$ & $\stackrel{\infty}{\infty}$ & $\triangleright$ & $\stackrel{\infty}{=}$ & $\stackrel{\Xi}{0}$ & ริ & 'f & 0 & $\stackrel{0}{ }$ & $=$ & 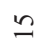 & $\underset{N}{ }$ & $\stackrel{\bullet}{ }$ & $\Xi$ & $\infty$ \\
\hline & & $\stackrel{+}{\sim}$ & & m & & 文 & & in & & t & & $\stackrel{ \pm}{ }$ & & $+\infty$ & \\
\hline
\end{tabular}


While organizing the industrial exploitation of peled whitefish it is more reasonable to orient the fishery to the fishing of fishes under three- six year age, as growth during this period is most intensive. Taking into account the high growth rate of Coregonus peled during the first - five years of life, the fishery is planned to be organized by the pasture fishery type, where by the reproduction process is carried out artificially and the younglings released into the reservoir, is cached already in 1-2 years time.

In lake Naiman Nuur all individuals became sexually mature at the age of $2+$ exceptionally already at the age of $1+$, at the minimum total length of $214 \mathrm{~mm}$ and minimum weight 295 g.Gonadosomatic index of mature females ranged 9 to $25 \%$, mean absolute fecundity averaged 58.060 eggs.

The first spawning of C. peled after its introduction in the Najman Nuur Lake system was observed in 1980 , i.e., in the age $2+$. During the autumn excursions carried out in following years 1981-1983 it was found that all 2+ years and exceptionally also $1+$ old individuals were mature and ready to take part in the following spawning (gonads occurred in the maturity stage IV $-\mathrm{V}$ according to $\mathrm{Nikolskij).} \mathrm{This} \mathrm{early}$ sexual maturation, both of the males and females, seems to be normal in the majority of acclimatized and fast growing populations [6.7].The earlier maturation is rather a consequence of plentiful food resources than of geographical latitude. The gonadosomatic index of mature females varied in the range 9-20 and in extreme cases reached $25 \%$ at an absolute weight of gonads of 160 to 250 g. The size (total length) of spawners ranged $323-560 \mathrm{~mm}$ and their weight 295-1700 g. The absolute fecundity varied in the range 23920 to 98160 eggs $(x=58060)$, the relative fecundity ranged 35200-81800 eggs/ $\mathrm{kg}^{-1}$. The average diameter of the ripened eggs reached $1.3-2.0 \mathrm{~mm}$. In 1982, an abundant spawning shoal formed and the first spawning took place of the offspring already born in the Najman Nuur lakes.

Coregonus peled valuable commercial target. It is relatively expensive. In the 19952005 catches varied from 3.5 to 50 tons a year. By the end of 2005, the abundance of C.peled significantly decreased to 25 tons a year. An annual ban on fishing was instituted during spawning period and is considered a sufficient conservation measure.

\section{References}

1. Dulmaa A. \& Milan Penaz. 1986. Observations on Coregonus peled (Pisces: Coregonidae) introduced in Mongolian waterbodies. Folia Zool. Brno, 35(3): 269-277.

2. Dulmaa A. \& Milan Penaz,. 1986. On the growth of Coregonus peled introduced to Mongolian waterbodies. Folia Zool. Brno, 35(4): 353-370.

3. Dulmaa A., Vlastimil Barus \& Milan Penaz. 1998. Morphometry of the possible natural hybrids Coregonus peled x C.autumnalis migratorius (Coregonidae) in the Mongolian Lake Ulaagchnii Char. Folia Zool. 47(1): 51-59.

4. Karacev G.L., Chodzer L.C., Mednaja L.I. 1979. Akklimatizacija peladi v Zabajkale [The acclimation of Coregonus peled in Transbaikalia]. Ryb. choz'ajsvo, 1979 (12) 16-17 (in Russian).

5. Pravdin I.F. 1966. Rukovodstvo po izuceniju ryb (Hand book of ichthyology). Pishc. Promyschlennost. Moskva. 355 pp. (in Russian).

6. Reshetnikov Yu.S.1980. Ekologija i sistematika sigovych ryb (Ecology and systematics of coregonid fishes). Nauka. Moskva. 302 pp. (in Russian.

7. Reshetnikov Yu.S.,Mukhachev I.S.,Bolotova N.L. 1989. Coregonus peled (Gmelin,1788). Systematics, Morphology, Ecology, Production. Nauka. Moskva 269 pp. (in Russian). 